\title{
Transit times from rainfall to baseflow in headwater catchments estimated using tritium: the Ovens River, Australia
}

\author{
I. Cartwright ${ }^{1,2}$ and U. Morgenstern ${ }^{3}$ \\ ${ }^{1}$ School of Earth, Atmosphere and Environment, Monash University, Clayton, Vic. 3800, Australia \\ ${ }^{2}$ National Centre for Groundwater Research and Training, GPO Box 2100, Flinders University, Adelaide, SA 5001, Australia \\ ${ }^{3}$ GNS Science, Lower Hutt 5040, New Zealand
}

Correspondence to: I. Cartwright (ian.cartwright@monash.edu)

Received: 29 April 2015 - Published in Hydrol. Earth Syst. Sci. Discuss.: 11 June 2015

Revised: 28 August 2015 - Accepted: 31 August 2015 - Published: 8 September 2015

\begin{abstract}
Headwater streams contribute a significant proportion of the total flow to many river systems, especially during summer low-flow periods. However, despite their importance, the time taken for water to travel through headwater catchments and into the streams (the transit time) is poorly understood. Here, ${ }^{3} \mathrm{H}$ activities of stream water are used to define transit times of water contributing to streams from the upper reaches of the Ovens River in south-east Australia at varying flow conditions. ${ }^{3} \mathrm{H}$ activities of the stream water varied from 1.63 to $2.45 \mathrm{TU}$, which are below the average ${ }^{3} \mathrm{H}$ activity of modern local rainfall (2.85 to $\left.2.99 \mathrm{TU}\right)$. The highest ${ }^{3} \mathrm{H}$ activities were recorded following higher winter flows and the lowest ${ }^{3} \mathrm{H}$ activities were recorded at summer low-flow conditions. Variations of major ion concentrations and ${ }^{3} \mathrm{H}$ activities with streamflow imply that different stores of water from within the catchment (e.g. from the soil or regolith) are mobilised during rainfall events rather than there being simple dilution of an older groundwater component by event water. Mean transit times calculated using an exponential-piston flow model range from 4 to 30 years and are higher at summer low-flow conditions. Mean transit times calculated using other flow models (e.g. exponential flow or dispersion) are similar. There are broad correlations between ${ }^{3} \mathrm{H}$ activities and the percentage of rainfall exported from each catchment and between ${ }^{3} \mathrm{H}$ activities and $\mathrm{Na}$ and $\mathrm{Cl}$ concentrations that allow first-order estimates of mean transit times in adjacent catchments or at different times in these catchments to be made. Water from the upper Ovens River has similar mean transit times to the headwater streams implying there is no significant input of old water from the alluvial gravels. The observation that the water contributing
\end{abstract}

to the headwater streams in the Ovens catchment has a mean transit time of years to decades implies that these streams are buffered against rainfall variations on timescales of a few years. However, impacts of any changes to land use in these catchments may take years to decades to manifest themselves in changes to streamflow or water quality.

\section{Introduction}

Documenting the timescales over which rainfall is transmitted through catchments to streams (the transit time) is critical for understanding catchment hydrology and for the protection and management of river systems. While there has been an increasing number of studies that have estimated transit times (e.g. Kirchner et al., 2010; McDonnell et al., 2010; Morgenstern et al., 2010, 2015; Hrachowitz et al., 2013), the time taken for water to be transformed from rainfall to stream baseflow remains poorly understood in many catchments. Likewise the factors that control variations in transit times between catchments are not well documented.

Perennial streams, especially in arid or semi-arid regions, are commonly sustained by groundwater inflows during lowflow periods (Winter, 1999; Sophocleous, 2002). Where the lower and middle reaches of rivers are developed on alluvial sediments, these sediments provide a ready source of groundwater to sustain the river during low-flow periods. River systems in limestone terrains are likewise sustained by drainage through karst systems. By contrast, headwater catchments that are developed on indurated or crystalline rocks may not be linked to well-developed groundwater sys- 
tems. The observation that many headwater streams continue to flow over prolonged dry periods indicates, however, that these catchments contain stores of water in soils, weathered rocks, or fractures with retention times of at least a few years (e.g. Maloszewski and Zuber, 1982; Maloszewski et al., 1992; Rice and Hornberger, 1998; Maloszewski, 2000). However, the transit times of water within these stores and whether different stores are more active at different times, for example during high vs. low rainfall periods, is not well known.

At times of low flow, much of the water in streams and rivers is likely derived from long-term stores such as groundwater (Sophocleous, 2002; McCallum et al., 2010; Cook, 2013). Less well understood is the extent to which older water rather than event water (i.e. that derived from recent rainfall) contributes to higher streamflows. In some catchments at least, rainfall appears to displace water from the soils and regolith and increase groundwater inflows to streams due to hydraulic loading. In these cases relatively old water may still contribute a significant volume of water to the river at higher streamflows (Sklash and Farvolden, 1979; Rice and Hornberger, 1998; Kirchner, 2009; Hrachowitz et al., 2011).

Understanding the timescales of water movement within headwater catchments is an essential part of water management. Headwater streams contribute a significant proportion of the total flow of many river systems (Freeman et al., 2007). Thus the water provided by headwater streams is that which may be eventually used downstream for domestic use, recreation, agriculture, and/or industry. Many headwater catchments retain native vegetation; however, increasing population growth and economic development has seen progressive changes of land use, including plantation forestry, agriculture, and urban development. The impacts of such development on the headwater catchments, and consequently on the river systems as a whole, is currently poorly understood.

Identifying first-order controls on transit times aids the prediction of likely transit times in adjacent catchments. Geology, vegetation, and soil types, which influence recharge rates and groundwater fluxes, may be important controls on transit times. Catchment area and the drainage density (the length of stream per unit area of catchment) may also be important controls on transit times (Morgenstern et al., 2015). Larger catchments are likely to have longer flow paths which result in longer transit times. However, if the catchment contains a higher density of streams there may be numerous short flow paths between recharge areas and discharge points in the streams. Additionally, transit times may correlate with the proportion of rainfall exported from the catchment by the stream (the runoff coefficient). This is because catchments with low runoff coefficients are likely to have higher evapotranspiration rates which lead to low infiltration rates and relatively slow passage of water through the catchment.

\subsection{Determining water transit times}

There are several methods that may be used to estimate the time taken for water to transit through a catchment to the stream. The temporal variation of stable isotope ratios and/or major ion concentrations in rainfall become attenuated with increasing transit times as mixing of water derived from different rainfall episodes occurs within the catchment (Kirchner, 2009; Kirchner et al., 2010; Hrachowitz et al., 2013). When combined with lumped parameter models that describe the distribution of residence times along flow paths in a catchment (e.g. Maloszewski and Zuber, 1982; Maloszewski, 2000), the variation in geochemistry at the catchment outlet can be used to quantify water transit times. While this methodology has been applied with some success, there are some limitations. Firstly, it requires detailed (preferably at least weekly) stable isotope and/or major ion geochemistry data for rainfall collected over a period which exceeds that of the transit times of water in the catchment. Such data are not commonly available, especially where transit times are more than a few years. Secondly, a single estimate of the transit time is commonly estimated for the catchment whereas water with different transit times may contribute to the stream at low and higher flows (e.g. Morgenstern et al., 2010, 2015). Seasonal variations in flow within the catchment may also attenuate variations in the concentrations of these tracers (Kirchner, 2015). Finally, these tracers are progressively more ineffective where transit times are in excess of 4-5 years as the temporal variations are smoothed out (Stewart et al., 2010).

Tritium $\left({ }^{3} \mathrm{H}\right)$, which has a half-life of 12.32 years, may also be used to determine transit times of relatively young $(<100$ years $)$ groundwater into streams using lumped parameter models. ${ }^{3} \mathrm{H}$ is part of the water molecule and its abundance in water is only affected by initial activities and radioactive decay, and not by reactions between the water and the aquifer matrix, as is the case with some solute tracers such as ${ }^{14} \mathrm{C}$ or ${ }^{32} \mathrm{Si}$. Other potential tracers such as ${ }^{3} \mathrm{He}$, the chlorofluorocarbons, and $\mathrm{SF}_{6}$ are gases that equilibrate with the atmosphere and are difficult to use in streams. The ${ }^{3} \mathrm{H}$ activities in rainfall have been measured globally for several decades (e.g. International Atomic Energy Association, 2015; Tadros et al., 2014) and these may be used to define the input of ${ }^{3} \mathrm{H}$ into the catchment. Rainfall ${ }^{3} \mathrm{H}$ activities have a distinct peak in the 1950s to 1960 s due to the production of ${ }^{3} \mathrm{H}$ in the atmospheric nuclear tests (the so-called "bomb pulse"). Traditionally, the propagation of the bomb pulse has been used to trace the flow of water recharged during this period (Fritz et al., 1991; Clark and Fritz, 1997) because single measurements of ${ }^{3} \mathrm{H}$ activities yielded non-unique estimates of transit times. However, because ${ }^{3} \mathrm{H}$ activities during the bomb pulse were several orders of magnitude lower in the Southern Hemisphere than in the Northern Hemisphere (Clark and Fritz, 1997; Morgenstern et al., 2010; Tadros et al., 2014), ${ }^{3} \mathrm{H}$ activities of remnant bomb pulse water in 
the Southern Hemisphere have decayed well below those of modern rainfall. This situation results in unique transit times being estimated from single ${ }^{3} \mathrm{H}$ measurements (Morgenstern et al., 2010; Morgenstern and Daughney, 2012), which in turn permits the transit time of water contributing to streams at specific flow conditions to be determined.

There is always uncertainty in calculating transit or residence times using lumped parameter models as they are a simplification of the flow system. However, since the bombpulse ${ }^{3} \mathrm{H}$ has mostly disappeared in the Southern Hemisphere, ${ }^{3} \mathrm{H}$ activities reflect relative transit times that do not depend on the applicability of the assumed model (i.e. water with low ${ }^{3} \mathrm{H}$ activities has longer mean transit times than water with high ${ }^{3} \mathrm{H}$ activities). This allows ${ }^{3} \mathrm{H}$ activities to be readily compared with other parameters (e.g. streamflow or major ion compositions). By contrast, as discussed above, for Northern Hemisphere waters individual ${ }^{3} \mathrm{H}$ activities do not yield unique residence times and comparisons can only be made with transit times derived from time series of ${ }^{3} \mathrm{H}$ activities that are inherently model dependant.

\subsection{Qualitative water transit time indicators}

In many catchments, including the Ovens, the concentration of major ions in groundwater increases with time (Edmunds et al., 1982; Bullen et al., 1996; Zuber et al., 2005; Morgenstern et al., 2010; Cartwright and Morgenstern, 2012). Thus, major ion concentrations in stream water can also provide an indication of the relative transit time of water that contributes to the stream. There may also be a correlation between streamflow and transit times (Morgenstern et al., 2010). As major ion concentrations and streamflow data are easier to obtain than ${ }^{3} \mathrm{H}$ activities and commonly already exist, such correlations offer the possibility of providing firstorder estimates of transit times in adjacent catchments or to periods when no ${ }^{3} \mathrm{H}$ activities were measured.

\subsection{Aims and objectives}

The aim of this paper is to understand the transit times of baseflow, here defined as including all non-surface water sources including soil water, interflow, and groundwater, contributing to headwater streams in the Ovens catchment, south-east Australia using ${ }^{3} \mathrm{H}$ activities and major ion concentrations. Specifically, we use these data to test the following hypotheses. Firstly, that transit times in individual catchments vary with streamflow as different water stores in the catchments are mobilised. Secondly, that there are first-order controls on transit times, such as catchment area, geology, land use, catchment size, or the runoff coefficient. Finally, that the concentration of major ions will increase with residence time in the catchment and can be used as proxies for the transit time. While this study is based in the Ovens catchment, understanding the first order controls on water transit times or whether there are proxies that may be used to es-

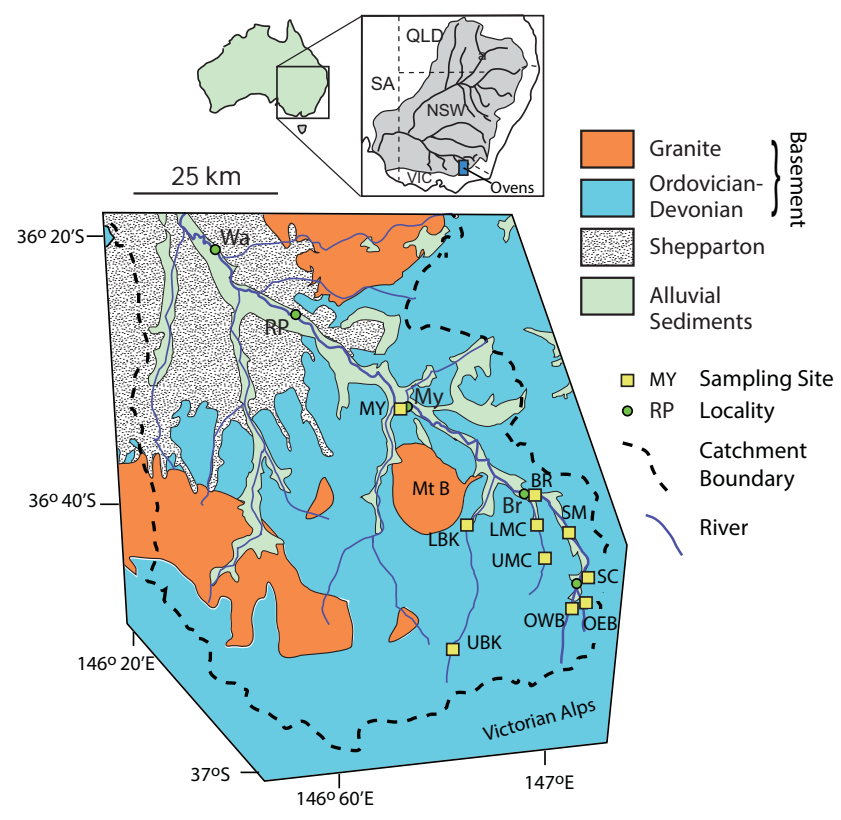

Figure 1. Summary geological and location map of the Ovens catchment, data from Energy and Earth Resources (2015). Sampling sites: $\mathrm{BR}=$ Bright, $\mathrm{LBK}=$ Lower Buckland, $\mathrm{LMC}=$ Lower Morses Creek, $\mathrm{MY}=$ Myrtleford, OEB = Ovens East Branch, $\mathrm{OWB}=$ Ovens West Branch, $\mathrm{SC}=$ Simmons Creek, $\mathrm{SM}=$ Smoko, $\mathrm{UBK}=$ Upper Buckland, UMC $=$ Upper Morses Creek. Localities: $\mathrm{Br}=$ Bright, $\mathrm{Ha}=$ Harrietville, $\mathrm{My}=$ Myrtleford, Mt $\mathrm{B}=$ Mount Buffalo; RP $=$ Rocky Point, $\mathrm{Wa}=$ Wangaratta. Inset map shows location of Ovens Valley relative to the Murray-Darling Basin (shaded); NSW = New South Wales, QLD = Queensland, $\mathrm{SA}=$ South Australia, VIC $=$ Victoria.

timate transit times has an application to other catchments globally.

\section{Setting}

The Ovens River is part of the Murray-Darling River system (Lawrence, 1988). The Ovens River is perennial with a length of approximately $200 \mathrm{~km}$ and its headwaters extend into the Victorian Alps (Fig. 1). It has a single channel confined within a steep-sided valley south (upstream) of Myrtleford and then develops into a network of meandering and anastomosing channels north of Wangaratta prior to its confluence with the Murray River. This study concentrates on the upper reaches of the Ovens catchment upstream of Myrtleford (Fig. 1), which includes several headwater tributaries, notably the Buckland River, Morses Creek, and the East and West Branches of the Ovens River.

The upper Ovens catchment is dominated by metamorphosed Ordovician turbidites and Silurian to Devonian granite intrusions (Fig. 1). These rocks form fracturedrock aquifers that have hydraulic conductivities of 0.01 to $1 \mathrm{~m} \mathrm{day}^{-1}$ with higher hydraulic conductivities occurring in 
weathered zones mainly close to the land surface (Shugg, 1987; van den Berg and Morand, 1997). The basement rocks are overlain by sediments of the Quaternary Shepparton Formation and the Holocene Coonambidgal Formation that in this area are contiguous and indistinguishable. These two formations occur in the river valleys and comprise unconsolidated and generally poorly sorted immature fluvio-lacustrine sands, gravels, silts and clays (Tickell, 1978; Shugg, 1987; Lawrence, 1988). The Shepparton and Coonambidgal Formations increase in thickness away from the Victorian Alps and reach a maximum thickness of $170 \mathrm{~m}$ in the lower Ovens Valley; however, where present in the upper Ovens catchment, they are $<50 \mathrm{~m}$ thick and thin out considerably in the tributary valleys. The hydraulic conductivity of the Shepparton and Coonambidgal Formations varies from 0.1 to $60 \mathrm{~m} \mathrm{day}^{-1}$ with typical values of 0.2 to $5 \mathrm{~m} \mathrm{day}^{-1}$ (Tickell, 1978; Shugg, 1987). Alluvial fans that are locally tens of metres thick and which comprise of coarse-grained poorly sorted immature sediments commonly occur between the basement rocks and the floodplain.

The upper reaches of the Ovens River and its tributaries are characterised by narrow steep-sided valleys that are dominated by native eucalyptus forest with subordinate pine plantations. The Ovens Valley broadens downstream of Harrietville (Fig. 1) and alluvial flats up to $2 \mathrm{~km}$ wide are developed adjacent to the Ovens River and in the lower reaches of the tributaries. These alluvial flats together with some of the alluvial fans have been cleared for agriculture, which includes cattle grazing, orchards, vineyards, hops, and fruit farms. The population of the upper Ovens Valley is $\sim 7500$, mainly in the towns of Myrtleford, Bright, and Harrietville. This part of the Ovens catchment contains no reservoirs and, while there is some use of surface and groundwater, the flow regimes in the upper Ovens catchment are considered to be little impacted (Goulburn-Murray Water, 2015).

Average precipitation decreases from $1420 \mathrm{~mm} \mathrm{yr}^{-1}$ in the alpine region to $1170 \mathrm{~mm} \mathrm{yr}^{-1}$ at Bright (Bureau of Meteorology, 2015). Approximately $45 \%$ of the annual precipitation occurs in the austral winter (June to September) with a proportion of the winter precipitation occurring as snow on the higher peaks, while March has the lowest precipitation (5 to $6 \%$ of the annual total). Streamflow in the Ovens River at Bright (Fig. 1) between 1924 and 2014 was between 1000 and $3.28 \times 10^{7} \mathrm{~m}^{3}$ day $^{-1}$ with high flows occurring in winter (Department of Environment and Primary Industries, 2015).

\section{Sampling and analytical methods}

\subsection{Sampling sites}

The sampling sites in this study have been designated as being from headwater catchments or floodplain areas. The headwater catchment areas are dominantly composed of basement rocks covered with eucalyptus forest and subordinate plantation forest. Alluvial sediments in these catchments are restricted to zones of a few metres to tens of metres wide immediately adjacent to the streams. The Ovens East Branch (catchment area of $72 \mathrm{~km}^{2}$ ), Ovens West Branch (catchment area of $42 \mathrm{~km}^{2}$ ), and Simmons Creek (catchment area of $6 \mathrm{~km}^{2}$ ) were sampled at Harrietville close to where these streams enter the floodplain of the Ovens Valley. The upper Buckland River (catchment area of $77 \mathrm{~km}^{2}$ ) and upper Morses Creek (catchment area of $32 \mathrm{~km}^{2}$ ) are from the upper reaches of those tributaries that are largely undeveloped. The lower Buckland River (catchment area of $435 \mathrm{~km}^{2}$ ) and lower Morses Creek (catchment area of $123 \mathrm{~km}^{2}$ ) have some land clearing on the lower parts of alluvial fans and the floodplain. Together these streams represent the main tributaries in the upper Ovens Valley (Fig. 1).

The floodplain sites are on the main Ovens River (Fig. 1, Table 1). Here the floodplain is up to $2 \mathrm{~km}$ wide and is underlain by coarse-grained alluvial sediments that are up to $50 \mathrm{~m}$ thick. The floodplain and some of the lower slopes of the alluvial fans have been cleared while the upper slopes are still dominated by eucalyptus forests with subordinate pine plantations. The Smoko (catchment area of $267 \mathrm{~km}^{2}$ ) and Bright (catchment area of $302 \mathrm{~km}^{2}$ ) sampling sites are upstream of the junction with Morses Creek and downstream of the Ovens East Branch, Ovens West Branch and Simmons Creek tributaries. The Myrtleford sampling site (catchment area of $1240 \mathrm{~km}^{2}$ ) is downstream of the junction with the Buckland River and upstream of the junction with the Buffalo River (not sampled in this study). Sampling took place in four rounds (Table 1, Fig. 2) that represent a variety of flow conditions.

\subsection{Streamflow measurements}

Streamflow is monitored at or close to the Myrtleford, Bright, Ovens West Branch (until 1989), Simmons Creek, Lower Buckland, and Lower Morses Creek sampling sites (Department of Environment and Primary Industries, 2015). A gauge at Harrietville (Fig. 1) records the combined streamflow from the Ovens West Branch and Ovens East Branch tributaries. The average daily combined streamflow at Harrietville and that of the Ovens West Branch are well correlated over a wide range of flows $\left(n=1012, R^{2}=0.97\right)$ allowing the streamflow of the Ovens West Branch for the sampling rounds in this study to be calculated from the Harrietville streamflow. In turn, this enables the contribution of Ovens East Branch tributary to the combined flows to be estimated.

\subsection{Geochemical sampling}

Stream water was sampled from swiftly-flowing stream sections using a collector fixed to an extendable pole. Rainfall was collected from two rainfall collectors located at Mount Buffalo (Fig. 1). Cations were analysed at Monash University 
Table 1. Geochemistry of the Ovens River and tributaries.

\begin{tabular}{|c|c|c|c|c|c|c|c|}
\hline Site $^{\mathrm{a}}$ & $\begin{array}{r}\text { Area } \\
\mathrm{km}^{2}\end{array}$ & $\begin{array}{l}\text { Streamflow } \\
10^{3} \mathrm{~m}^{3} \text { day }^{-1}\end{array}$ & $\begin{array}{l}{ }^{3} \mathrm{H} \\
\mathrm{TU}\end{array}$ & $\begin{array}{c}\delta^{18} \mathrm{O} \\
\% \circ \text { SMOW }\end{array}$ & $\begin{array}{c}\delta^{2} \mathrm{H} \\
\% \circ \text { SMOW }\end{array}$ & $\begin{array}{c}\mathrm{Cl} \\
\mathrm{mg} \mathrm{L}^{-1}\end{array}$ & $\begin{array}{c}\mathrm{Na} \\
\mathrm{mg} \mathrm{L}^{-1}\end{array}$ \\
\hline \multicolumn{8}{|c|}{ December 2013} \\
\hline Ovens East Branch & 72 & 110 & $2.265 \pm 0.035^{\mathrm{d}}$ & -7.5 & -41 & 0.93 & 2.26 \\
\hline Ovens West Branch & 42 & 44 & $2.168 \pm 0.037$ & -7.5 & -40 & 1.94 & 3.23 \\
\hline Simmons CK & 6 & 2.34 & $1.812 \pm 0.036$ & -7.3 & -41 & 2.49 & 4.21 \\
\hline Bright & 302 & 269 & $2.280 \pm 0.040$ & -7.4 & -40 & 1.36 & 2.88 \\
\hline Upper Morses Ck & 32 & & $2.134 \pm 0.036$ & -6.7 & -38 & 1.18 & 2.94 \\
\hline Lower Morses Ck & 123 & 34.2 & $2.032 \pm 0.036$ & -6.8 & -37 & 1.25 & 2.91 \\
\hline Upper Buckland & 77 & & $2.186 \pm 0.040$ & -7.2 & -41 & 0.82 & 3.43 \\
\hline Lower Buckland & 435 & 181 & $2.253 \pm 0.036$ & -7.0 & -39 & 1.13 & 3.49 \\
\hline Myrtleford & 1240 & 784 & $2.243 \pm 0.036$ & -6.7 & -38 & 1.43 & 2.72 \\
\hline Buffalo Rain & & & $2.986 \pm 0.046$ & & & 1.10 & 0.87 \\
\hline \multicolumn{8}{|c|}{ February 2014} \\
\hline Ovens East Branch & 72 & 15.9 & $2.189 \pm 0.046$ & -7.1 & -41 & 1.73 & 3.34 \\
\hline Ovens West Branch & 42 & 4.2 & $1.974 \pm 0.037$ & -7.1 & -41 & 3.44 & 5.49 \\
\hline Simmons CK & 6 & 1.13 & $1.634 \pm 0.032$ & -7.3 & -42 & 3.47 & 4.78 \\
\hline Smoko & 267 & & $2.088 \pm 0.042$ & -7.1 & -40 & 2.61 & 4.62 \\
\hline Bright & 302 & 64.6 & $1.988 \pm 0.044$ & -7.0 & -39 & 1.81 & 3.21 \\
\hline Upper Morses Ck & 32 & 5.59 & $1.920 \pm 0.034$ & -6.5 & -35 & 1.12 & 4.08 \\
\hline Lower Morses Ck & 123 & & $1.980 \pm 0.040$ & -6.4 & -36 & 1.34 & 4.19 \\
\hline Upper Buckland & 77 & 33.7 & $2.097 \pm 0.036$ & -7.2 & -41 & 1.36 & 3.49 \\
\hline Lower Buckland & 435 & 85.8 & $2.039 \pm 0.036$ & -6.5 & -38 & 1.82 & 3.47 \\
\hline Myrtleford & 1240 & & $2.074 \pm 0.036$ & -6.8 & -39 & 1.97 & 3.45 \\
\hline Buffalo Rain & & & $2.859 \pm 0.049$ & & & & \\
\hline \multicolumn{8}{|c|}{ July 2014} \\
\hline Ovens East Branch & 72 & 407 & $2.327 \pm 0.046$ & -7.4 & -41 & 0.92 & 2.04 \\
\hline Ovens West Branch & 42 & 179 & $2.303 \pm 0.042$ & -7.3 & -40 & 1.17 & 2.65 \\
\hline Simmons CK & 6 & 10.5 & $2.121 \pm 0.041$ & -7.4 & -41 & 1.63 & 3.37 \\
\hline Smoko & 267 & & $2.322 \pm 0.043$ & -7.3 & -40 & 0.97 & 2.49 \\
\hline Bright & 302 & 1566 & $2.340 \pm 0.045$ & -7.2 & -39 & 1.39 & 2.66 \\
\hline Upper Morses Ck & 32 & & $2.306 \pm 0.047$ & -6.9 & -37 & 1.12 & 2.76 \\
\hline Lower Morses Ck & 123 & 301 & $2.259 \pm 0.042$ & -7.1 & -38 & 1.19 & 2.95 \\
\hline Upper Buckland & 77 & & $2.431 \pm 0.044$ & -7.3 & -40 & 1.21 & 3.02 \\
\hline Lower Buckland & 435 & 1111 & $2.381 \pm 0.039$ & -7.1 & -39 & 1.53 & 2.95 \\
\hline Myrtleford & 1240 & 3925 & $2.306 \pm 0.038$ & -7.0 & -38 & 1.66 & 2.87 \\
\hline Buffalo Rain & & & $2.521 \pm 0.043$ & & & & \\
\hline \multicolumn{8}{|c|}{ September 2014} \\
\hline Ovens East Branch & 72 & 60.6 & $2.446 \pm 0.045$ & -7.5 & -41 & 1.14 & 2.42 \\
\hline Ovens West Branch & 42 & 24.1 & $2.191 \pm 0.038$ & -7.3 & -40 & 1.29 & 3.40 \\
\hline Simmons CK & 6 & 4.43 & $1.893 \pm 0.034$ & -7.3 & -41 & 1.55 & 4.58 \\
\hline Smoko & 267 & & $2.240 \pm 0.038$ & -7.2 & -41 & 1.29 & 2.72 \\
\hline Bright & 302 & 319 & $2.278 \pm 0.037$ & -7.1 & -40 & 1.50 & 3.31 \\
\hline Upper Morses Ck & 32 & & $2.163 \pm 0.036$ & -6.8 & -37 & 1.55 & 3.16 \\
\hline Lower Morses Ck & 123 & 48.3 & $2.065 \pm 0.035$ & -6.7 & -36 & 1.70 & 3.46 \\
\hline Upper Buckland & 77 & & $2.226 \pm 0.038$ & -7.2 & -40 & 1.63 & 3.14 \\
\hline Lower Buckland & 435 & 255 & $2.314 \pm 0.037$ & -6.7 & -39 & 1.61 & 3.19 \\
\hline Myrtleford & 1240 & 747 & $2.272 \pm 0.038$ & -6.8 & -39 & 1.89 & 3.28 \\
\hline Buffalo Rain & & & $2.714 \pm 0.044$ & & & & \\
\hline Buffalo Rain $2^{f}$ & & & $2.850 \pm 0.057$ & & & & \\
\hline
\end{tabular}

${ }^{\mathrm{a}}$ Localities on Fig. 1. ${ }^{\mathrm{b}}$ Area of catchment upstream of sampling site. ${ }^{\mathrm{c}}$ River discharge. Discharge for Ovens East Branch and Ovens West Branch estimated from the Harrietville gauge as discussed in text. ${ }^{\mathrm{d}}$ The tritium error is individually calibrated and calculated for each sample as described by Morgenstern and Taylor (2009). ${ }^{\mathrm{f}} 12$ month aggregated sample from second rain collector, collected in March 2015. 

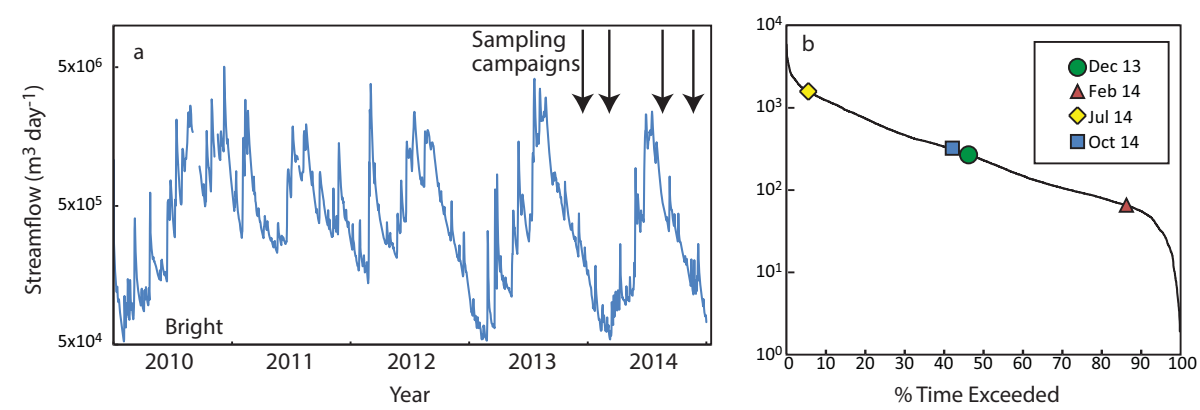

Figure 2. (a) Flow of the Ovens River at Bright between 2009 and 2014, arrows show timing of sampling campaigns. (b) Flow duration curve for Bright. Data from Department of Environment Primary Industries (2015).

using a ThermoFinnigan ICP-OES or ICP-MS on samples that had been filtered through $0.45 \mu \mathrm{m}$ cellulose nitrate filters and acidified to $\mathrm{pH}<2$ using double-distilled $16 \mathrm{M} \mathrm{HNO}_{3}$. Anions were analysed on filtered unacidified samples using a Metrohm ion chromatograph at Monash University. The precision of anion and cation analyses based on replicate analyses is $\pm 2 \%$ and the accuracy based on analysis of certified water standards is $\pm 5 \%$. While a range of major ion concentrations were measured only $\mathrm{Cl}$ and $\mathrm{Na}$, which represent the major anion and cation in surface water and groundwater, are discussed here. Additional major ion data are from the Department of Environment and Primary Industries (2015).

Stable isotopes were measured at Monash University using Finnigan MAT 252 and ThermoFinnigan DeltaPlus Advantage mass spectrometers. $\delta^{18} \mathrm{O}$ values were determined via equilibration with $\mathrm{He}-\mathrm{CO}_{2}$ at $32{ }^{\circ} \mathrm{C}$ for $24-48 \mathrm{~h}$ in a ThermoFinnigan Gas Bench. $\delta^{2} \mathrm{H}$ was measured by reaction with $\mathrm{Cr}$ at $850^{\circ} \mathrm{C}$ using an automated Finnigan MAT H/Device. $\delta^{18} \mathrm{O}$ and $\delta^{2} \mathrm{H}$ values were measured relative to internal standards calibrated using IAEA SMOW, GISP and SLAP. Data were normalized following (Coplen, 1988) and are expressed relative to V-SMOW. Precision $(1 \sigma)$ based on replicate analysis is $\delta^{18} \mathrm{O}= \pm 0.1 \%$ and $\delta^{2} \mathrm{H}= \pm 1 \%$ o. ${ }^{3} \mathrm{H}$ activities are expressed in tritium units (TU) where $1 \mathrm{TU}$ represents a ${ }^{3} \mathrm{H} /{ }^{1} \mathrm{H}$ ratio of $1 \times 10^{-18}$. Samples for ${ }^{3} \mathrm{H}$ were vacuum distilled and electrolytically enriched prior to being analysed by liquid scintillation spectrometry using Quantulus ultra-lowlevel counters at GNS, New Zealand. Following from Morgenstern and Taylor (2009) the sensitivity is now further increased to a lower detection limit of $0.02 \mathrm{TU}$ via tritium enrichment by a factor of 95 , and reproducibility of tritium enrichment of $1 \%$ is achieved via deuterium-calibration for every sample. The precision $(1 \sigma)$ is $\sim 1.8 \%$ at $2 \mathrm{TU}$ (Table 1 ).

\subsection{Estimating mean transit times using ${ }^{3} \mathrm{H}$}

Water flowing through an aquifer follows flow paths of varying length, which results in the water discharging into streams having a range of transit times rather than a discrete age. The mean transit times may be calculated using the lumped parameter models described by Maloszewski and Zuber (1982, 1992), Cook and Bohlke (2000), Maloszewski (2000) and Zuber et al. (2005) that treat the discharging water as comprising numerous aliquots each of which has followed a different flow path and thus taken a different amount of time to pass through the aquifer. For steadystate groundwater flow, the activity of ${ }^{3} \mathrm{H}$ in water discharging into the stream at time $t\left(C_{\mathrm{o}}(t)\right)$ is related to the input of ${ }^{3} \mathrm{H}\left(C_{\mathrm{i}}\right)$ over time via the convolution integral:

$C_{\mathrm{o}}(t)=\int_{0}^{\infty} C_{\mathrm{i}}(t-\tau) g(\tau) e^{-\lambda \tau} \mathrm{d} \tau$,

where $\tau$ is the transit time, $t-\tau$ is the time that the water entered the flow system, $\lambda$ is the decay constant $\left(0.0563 \mathrm{yr}^{-1}\right.$ for ${ }^{3} \mathrm{H}$ ), and $g(\tau)$ is the response function that describes the distribution of flow paths and transit times in the system.

The exponential flow model describes the mean transit time in homogeneous unconfined aquifers of constant thickness that receive uniform recharge and where flow paths from the entire aquifer thickness discharge to the stream. Piston flow assumes linear flow with no mixing within the aquifer, such that all water discharging to the stream at any one time has the same transit time. The exponential-piston flow model describes mean transit times in aquifers that have regions where flow paths have an exponential distribution and regions where flow paths have a linear distribution. For the exponential-piston flow model $g(\tau)$ in Eq. (1) is given by:

$$
\begin{aligned}
& g(\tau)=0 \text { for } \tau<\tau_{\mathrm{m}}(1-f) \\
& g(\tau)=\left(f \tau_{\mathrm{m}}\right)^{-1} e^{-\tau / f \tau_{\mathrm{m}}+1 / f-1} \text { for } \tau>\tau_{\mathrm{m}}(1-f),
\end{aligned}
$$

where $\tau_{\mathrm{m}}$ is the mean transit time and $f$ is the proportion of the aquifer volume that exhibits exponential flow. Where $f=1$, Eqs. (1) and (2) describe the distribution of transit times resulting from exponential flow while where $f=0$, Eqs. (1) and (2) describe the distribution of transit times resulting from piston flow. The calculations utilised the Excel workbook TracerLPM (Jurgens et al., 2012) that specifies the ratio of exponential to piston flow as an EPM ratio which is equivalent to $1 / f-1$. The dispersion model is 
an alternative lumped parameter model based on the onedimensional advection-dispersion transport in a semi-infinite medium. The response function for this model is:

$g(\tau)=\frac{1}{\tau \sqrt{4 \pi D_{\mathrm{P}} \tau / \tau_{\mathrm{m}}}} e^{-\left(\frac{\left(1-\tau / \tau_{\mathrm{m}}\right)^{2}}{4 D_{\mathrm{P}} \tau / \tau_{\mathrm{m}}}\right)}$,

where $D_{\mathrm{P}}$ is the dispersion parameter (unitless), which is the inverse of the more commonly reported Peclet Number. $D_{\mathrm{P}}=D /(v x)$, where $v$ is velocity $\left(\mathrm{mday}^{-1}\right), x$ is distance (m), and $D$ is the dispersion coefficient $\left(\mathrm{m}^{2} \mathrm{day}^{-1}\right)$. While the dispersion model is considered to be a less realistic conceptualisation of flow systems, it commonly reproduces the observed distribution of radioisotopes within aquifers (Maloszewski, 2000).

\subsection{Mass balance calculations}

If groundwater and rainfall have different major ion concentrations, stable isotope ratios, or ${ }^{3} \mathrm{H}$ activities, variations in these parameters with streamflow may be used to assess the degree of mixing of baseflow with event water (Sklash and Farvolden, 1979; Uhlenbrook et al., 2002; Godsey et al., 2009). In the case where baseflow to the stream remains relatively constant and increases in streamflow are due to additional event water, the proportion of baseflow in the stream $\left(X_{\mathrm{bf}}\right)$ is given by $Q_{\mathrm{bf}} / Q$ where $Q$ is the measured streamflow and $Q_{\mathrm{bf}}$ is the streamflow at baseflow conditions. The concentration of a component in the stream $\left(C_{\mathrm{st}}\right)$ at higher streamflows is given by:

$C_{\mathrm{st}}=X_{\mathrm{bf}} C_{\mathrm{bf}}+\left(1-X_{\mathrm{bf}}\right) C_{\mathrm{ew}}$,

where $C_{\mathrm{bf}}$ and $C_{\mathrm{ew}}$ are the concentrations in the baseflow and event water, respectively.

\section{Results}

\subsection{Streamflow variations}

Figure 2a summarises the variation in streamflow at Bright between 2010 and 2014 and Fig. 2b shows the distribution of the sampling rounds relative to the flow frequency curve for 1980 to 2014 daily streamflow at Bright. The July 2014 sampling round was during a recession period from winter high flows and the streamflow of $1.57 \times 10^{6} \mathrm{~m}^{3} \mathrm{day}^{-1}$ represents the 5.5 percentile of streamflow (i.e. streamflow of this value or higher was recorded on $5.5 \%$ of days during 1980 to 2014). The December 2013 and October 2014 sampling rounds represent periods of intermediate streamflow of $2.69 \times 10^{5}$ and $3.19 \times 10^{5} \mathrm{~m}^{3}$ day $^{-1}$, which correspond to the 46.3 and 42.1 percentiles of streamflow, respectively. The February 2014 sampling round represents typical late austral summer low-flow conditions. The streamflow at Bright during this sampling round of $6.46 \times 10^{4} \mathrm{~m}^{3}$ day $^{-1}$ was close to

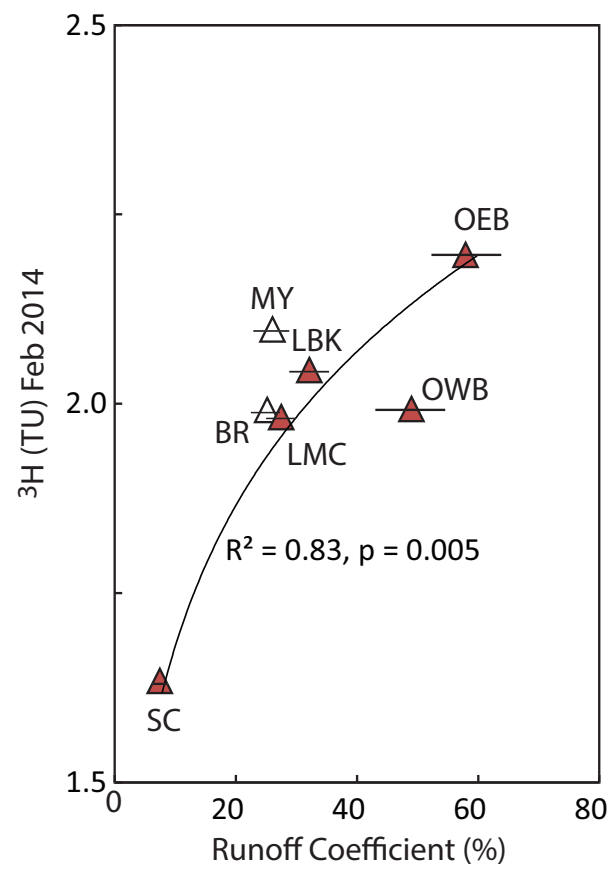

Figure 3. Runoff coefficient vs. ${ }^{3} \mathrm{H}$ activities for February 2014. Bars show range of runoff coefficients arising from the likely range of rainfall in the catchments, line is a logarithmic fit to the data that has an $R^{2}$ of 0.83 . Open symbols are sampling sites on the main Ovens River, closed symbols are from the headwater tributaries. $\mathrm{BR}=$ Bright, $\mathrm{LBK}=$ Lower Buckland, $\mathrm{LMC}=$ Lower Morses Creek, $\mathrm{OEB}=$ Ovens East Branch, OWB $=$ Ovens West Branch, $\mathrm{SC}=$ Simmons Creek. Data from Tables 1 and 2; precision of ${ }^{3} \mathrm{H}$ activities (Table 1 ) is approximately the size of the symbols.

the minimum streamflow for the 2013 to 2014 summer of $5.44 \times 10^{4} \mathrm{~m}^{3} \mathrm{day}^{-1}$ (Department of Environment and Primary Industries, 2015) and represents the 86.4 percentile of streamflow between 1980 and 2014.

The streamflow data may also be used to define the runoff coefficient (i.e. the percentage of rainfall exported from each catchment) (Fig. 3). The average annual streamflow was calculated using daily streamflow data between 1980 and 2014 (Department of Environment and Primary Industries, 2015). Periods of no record generally due to gauge malfunction were omitted; these represent $<15 \%$ of the data. There is a rainfall gradient across the Ovens catchment and insufficient rainfall stations to calculate area-weighted average rainfall for individual catchments. However, it is likely that precipitation in the whole region is between 1170 and $1420 \mathrm{~mm} \mathrm{yr}^{-1}$, which are the annual totals at Bright in the north of the catchment and the Victorian Alps to the south of the Ovens catchment. Using an average rainfall of $1295 \mathrm{~mm} \mathrm{yr}^{-1}$, runoff coefficients range from $\sim 7.4 \%$ for Simmons Creek to $\sim 58 \%$ for the Ovens East Branch. For the range of precipitation in the Ovens Valley the relative error of these runoff coefficients is $\sim 10 \%$. 

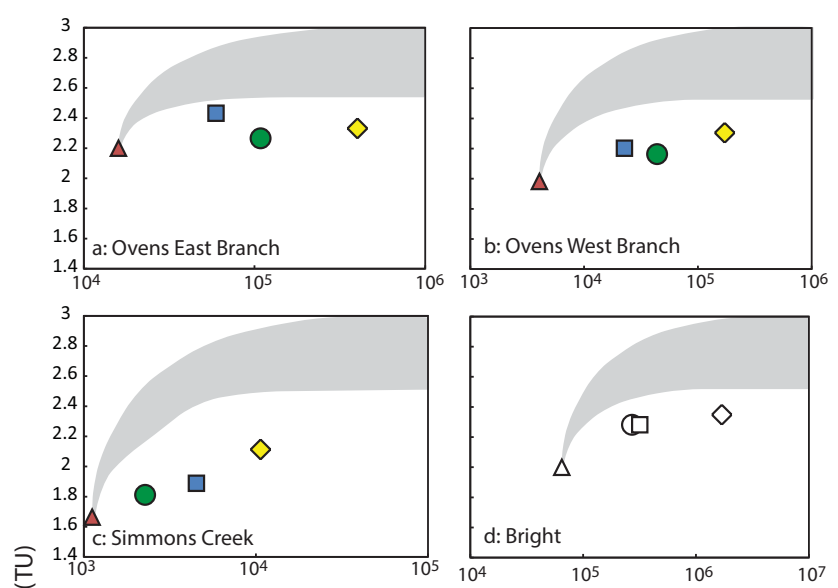

I
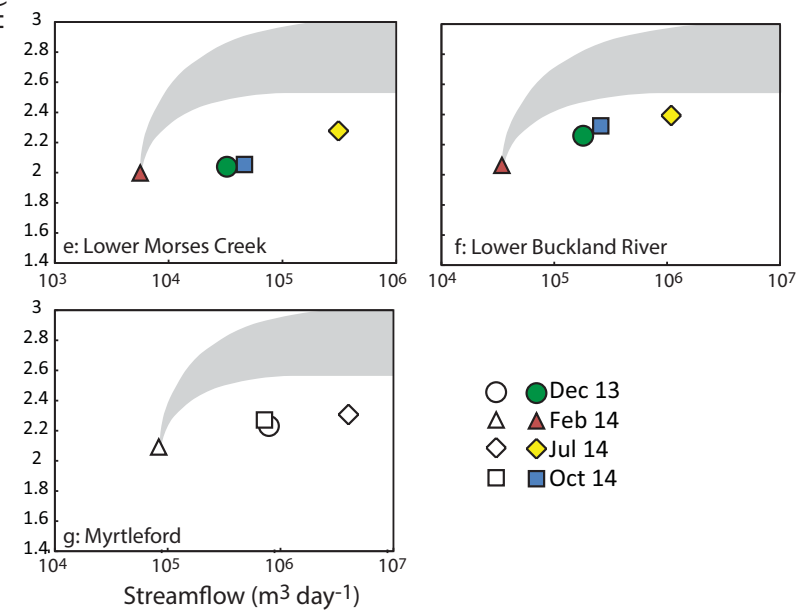

$$
\begin{array}{ll}
\bigcirc & \text { ODec } 13 \\
\Delta & \Delta \text { Feb } 14 \\
\diamond & \text { Dul } 14 \\
\square & \text { DOct } 14
\end{array}
$$

Streamflow $\left(\mathrm{m}^{3}\right.$ day $\left.^{-1}\right)$

Figure 4. ${ }^{3} \mathrm{H}$ activities vs. streamflow for the main Ovens River (open symbols) and its headwater tributaries (closed symbols); data from Table 1. Shaded fields depict mixing between baseflow, which is assumed to have a ${ }^{3} \mathrm{H}$ activity of the lowest streamflow at each site, and rainfall with a ${ }^{3} \mathrm{H}$ activity of between 2.5 and 3.0 TU, which spans the range of rainfall ${ }^{3} \mathrm{H}$ activities in Table 1 constructed using Eq. (4). The mixing model overestimates the ${ }^{3} \mathrm{H}$ activities recorded at higher flows at all sites.

\section{2 ${ }^{3} \mathrm{H}$ activities}

The rainfall sample from December 2013 represents a $\sim 17$ month aggregate sample from Mount Buffalo and has a ${ }^{3} \mathrm{H}$ activity of $2.99 \mathrm{TU}$ (Table 1 ). A second 12 month aggregate sample collected from a different site on Mount Buffalo in March 2015 has a ${ }^{3} \mathrm{H}$ activity of $2.85 \mathrm{TU}$ (Table 1). These ${ }^{3} \mathrm{H}$ activities are close to those expected for modern rainfall in south-east Australia (Tadros et al., 2014). Shorter timescale (2 to 5 month) rainfall samples collected from Mount Buffalo in February 2014, July 2014, and October 2014 have ${ }^{3} \mathrm{H}$ activities between 2.52 and $2.89 \mathrm{TU}$. The lowest ${ }^{3} \mathrm{H}$ activities from the rainfall are from rainfall collected between February and July 2014 in the austral autumn. Autumn and winter rains are commonly depleted in ${ }^{3} \mathrm{H}$ (Morgenstern et al., 2010; Tadros et al., 2014) as the main ${ }^{3} \mathrm{H}$ in-

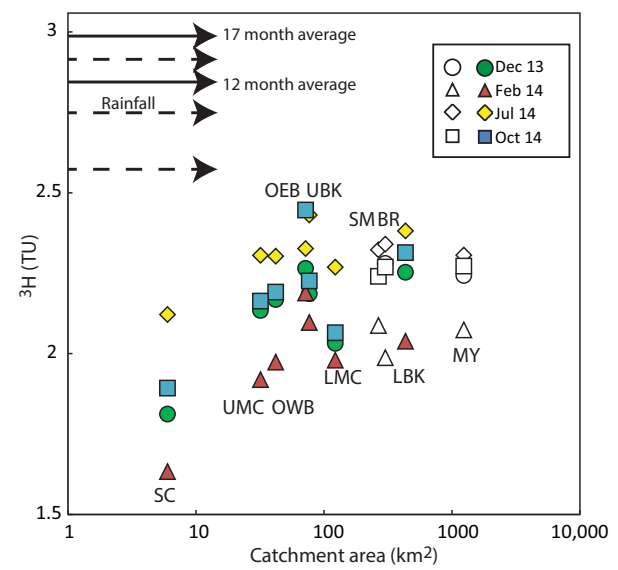

Figure 5. ${ }^{3} \mathrm{H}$ activities vs catchment area for the main Ovens River (open symbols) and its headwater tributaries (closed symbols) and the range of rainfall ${ }^{3} \mathrm{H}$ activities (aggregated rainfall samples shown by solid arrows, other rainfall samples by dashed arrows); data from Table 1 . BR $=$ Bright, $\mathrm{LBK}=$ Lower Buckland, $\mathrm{LMC}=$ Lower Morses Creek, $\mathrm{MY}=$ Myrtleford, $\mathrm{OEB}=$ Ovens East Branch, OWB $=$ Ovens West Branch, $\mathrm{SC}=$ Simmons Creek, $\mathrm{SM}=$ Smoko, $\mathrm{UBK}=$ Upper Buckland, $\mathrm{UMC}=$ Upper Morses Creek. Precision of ${ }^{3} \mathrm{H}$ activities (Table 1) is approximately the size of the symbols.

jection into the troposphere occurs in early spring. Stream water samples have ${ }^{3} \mathrm{H}$ activities between 1.63 and $2.43 \mathrm{TU}$ (Table 1), which are lower than all of the rainfall samples.

The highest ${ }^{3} \mathrm{H}$ activities of stream water at each sampling site are generally from the high-flow conditions in July 2014, while the lowest ${ }^{3} \mathrm{H}$ activities are from the February 2014 low-flow period (Table 1, Figs. 4 and 5). The ${ }^{3} \mathrm{H}$ activities from the three floodplain sites are similar to those of the headwater streams and there are no systematic downstream trends along the main Ovens River. Likewise there is little systematic variation in ${ }^{3} \mathrm{H}$ activities downstream in the Buckland River and Morses Creek. There is also not a positive correlation between catchment area and ${ }^{3} \mathrm{H}$ activities (Fig. 5); indeed, Simmons Creek, which is the smallest catchment, records the lowest ${ }^{3} \mathrm{H}$ activities in each sampling round. There is, however, a broad correlation between the runoff coefficient and ${ }^{3} \mathrm{H}$ activities as illustrated for the February 2014 samples in Fig. 3, with a similar relationship apparent in the other sampling campaigns (Tables 1 and 2).

\subsection{Major ion and stable isotope geochemistry}

The $\delta^{18} \mathrm{O}$ and $\delta^{2} \mathrm{H}$ values of the Ovens River from all the sampling rounds overlap (Fig. 6). Overall the $\delta^{18} \mathrm{O}$ and $\delta^{2} \mathrm{H}$ values define an array with a slope of $\sim 5.5$ and lowest $\delta^{18} \mathrm{O}$ and $\delta^{2} \mathrm{H}$ values of approximately -7.4 and $-41 \%$, respectively. In common with much groundwater and surface water in the Murray Basin the $\delta^{18} \mathrm{O}$ and $\delta^{2} \mathrm{H}$ values of the Ovens River lie to the left of the Meteoric Water Line, probably due 
Table 2. Calculated mean transit times for the Ovens River baseflow.

\begin{tabular}{|c|c|c|c|c|c|c|}
\hline \multirow[t]{2}{*}{ Site $^{\mathrm{a}}$} & \multirow{2}{*}{$\begin{array}{r}\mathrm{RC}^{\mathrm{b}} \\
\%\end{array}$} & \multicolumn{4}{|c|}{ Mean transit times (years) ${ }^{\mathrm{c}}$} & \multirow[b]{2}{*}{ Mean $^{\mathrm{e}}$} \\
\hline & & $\operatorname{EPF}(0.33)^{\mathrm{d}}$ & EPF (1.0) & $\mathrm{EF}$ & $\mathrm{DM}$ & \\
\hline \multicolumn{7}{|c|}{ December 2013} \\
\hline Ovens East Branch & $52.7-64.1$ & $7.2 \pm 0.7^{\mathrm{f}}$ & $6.9 \pm 0.6$ & $8.4 \pm 1.0$ & $7.3 \pm 0.4$ & $7.4 \pm 0.7$ \\
\hline Ovens West Branch & $43.4-52.6$ & $9.1 \pm 0.6$ & $9.4 \pm 0.1$ & $11.3 \pm 1.0$ & $9.0 \pm 0.2$ & $9.7 \pm 1.1$ \\
\hline Simmons CK & $6.7-8.1$ & $22.8 \pm 0.0$ & $17.7 \pm 0.0$ & $26.6 \pm 0.7$ & $16.4 \pm 0.0$ & $20.9 \pm 4.8$ \\
\hline Bright & $23.2-28.1$ & $6.9 \pm 0.7$ & $6.6 \pm 0.7$ & $8.0 \pm 1.0$ & $7.0 \pm 0.4$ & $7.1 \pm 0.6$ \\
\hline Upper Morses Ck & & $10.0 \pm 0.5$ & $10.0 \pm 0.1$ & $12.5 \pm 1.1$ & $9.8 \pm 0.4$ & $10.6 \pm 1.3$ \\
\hline Lower Morses Ck & $24.2-30.4$ & $13.0 \pm 0.4$ & $11.7 \pm 0.1$ & $16.9 \pm 1.0$ & $11.3 \pm 0.1$ & $13.2 \pm 2.5$ \\
\hline Upper Buckland & & $8.8 \pm 0.6$ & $8.9 \pm 0.2$ & $10.7 \pm 1.1$ & $8.8 \pm 0.1$ & $9.3 \pm 0.9$ \\
\hline Lower Buckland & $29.1-35.4$ & $7.6 \pm 0.8$ & $7.4 \pm 0.3$ & $8.7 \pm 1.0$ & $7.6 \pm 0.1$ & $7.8 \pm 0.6$ \\
\hline Myrtleford & $25.7-31.1$ & $7.8 \pm 0.8$ & $7.5 \pm 0.3$ & $9.0 \pm 1.0$ & $7.8 \pm 0.1$ & $8.0 \pm 0.7$ \\
\hline \multicolumn{7}{|c|}{ February 2014} \\
\hline Ovens East Branch & $52.7-64.1$ & $8.3 \pm 0.7$ & $8.0 \pm 0.5$ & $10.1 \pm 1.1$ & $8.2 \pm 0.3$ & $8.7 \pm 0.9$ \\
\hline Ovens West Branch & $43.4-52.6$ & $14.3 \pm 0.4$ & $12.6 \pm 0.0$ & $18.2 \pm 1.0$ & $12.2 \pm 0.1$ & $14.3 \pm 2.8$ \\
\hline Simmons CK & $6.7-8.1$ & $30.3 \pm 0.0$ & $25.8 \pm 0.0$ & $34.8 \pm 0.3$ & $28.7 \pm 0.0$ & $29.9 \pm 3.7$ \\
\hline Smoko & $23.2-28.1$ & $10.6 \pm 0.6$ & $10.6 \pm 0.1$ & $13.6 \pm 1.1$ & $9.9 \pm 0.3$ & $11.2 \pm 1.7$ \\
\hline Bright & & $13.8 \pm 0.4$ & $12.3 \pm 0.0$ & $17.8 \pm 10$ & $11.9 \pm 0.1$ & $13.9 \pm 2.7$ \\
\hline Upper Morses Ck & & $16.7 \pm 0.3$ & $13.7 \pm 0.0$ & $20.9 \pm 0.8$ & $13.3 \pm 0.1$ & $16.1 \pm 3.5$ \\
\hline Lower Morses Ck & $24.2-30.4$ & $14.1 \pm 0.4$ & $12.4 \pm 0.0$ & $18.2 \pm 1.0$ & $12.0 \pm 0.1$ & $14.2 \pm 2.8$ \\
\hline Upper Buckland & & $10.4 \pm 0.6$ & $10.5 \pm 0.1$ & $13.3 \pm 1.1$ & $10.0 \pm 0.3$ & $11.1 \pm 1.5$ \\
\hline Lower Buckland & $29.1-35.4$ & $12.1 \pm 0.5$ & $11.4 \pm 0.1$ & $15.6 \pm 1.0$ & $11.0 \pm 0.1$ & $12.5 \pm 2.1$ \\
\hline Myrtleford & $25.7-31.1$ & $11.0 \pm 0.5$ & $10.7 \pm 0.1$ & $14.2 \pm 1.1$ & $10.3 \pm 0.1$ & $11.6 \pm 1.8$ \\
\hline \multicolumn{7}{|c|}{ July 2014} \\
\hline Ovens East Branch & $52.7-64.1$ & $5.5 \pm 0.8$ & $4.9 \pm 0.9$ & $6.3 \pm 1.0$ & $4.9 \pm 0.9$ & $5.4 \pm 0.7$ \\
\hline Ovens West Branch & $43.4-52.6$ & $5.9 \pm 0.8$ & $5.2 \pm 0.8$ & $6.8 \pm 1.0$ & $5.3 \pm 0.9$ & $5.8 \pm 0.7$ \\
\hline Simmons CK & $6.7-8.1$ & $9.1 \pm 0.7$ & $8.6 \pm 0.5$ & $11.5 \pm 1.1$ & $8.8 \pm 0.3$ & $9.5 \pm 1.3$ \\
\hline Smoko & $23.2-28.1$ & $5.7 \pm 0.9$ & $5.0 \pm 0.8$ & $6.4 \pm 0.9$ & $5.0 \pm 0.9$ & $5.5 \pm 0.7$ \\
\hline Bright & & $5.3 \pm 1.0$ & $4.7 \pm 0.8$ & $6.1 \pm 1.0$ & $4.7 \pm 0.9$ & $5.2 \pm 0.6$ \\
\hline Upper Morses Ck & & $5.8 \pm 0.8$ & $5.2 \pm 0.8$ & $6.7 \pm 1.0$ & $5.3 \pm 0.9$ & $5.8 \pm 0.7$ \\
\hline Lower Morses Ck & $24.2-30.4$ & $6.4 \pm 0.7$ & $5.8 \pm 0.8$ & $7.5 \pm 1.0$ & $5.9 \pm 0.8$ & $6.4 \pm 0.8$ \\
\hline Upper Buckland & & $4.1 \pm 0.8$ & $3.7 \pm 0.8$ & $4.6 \pm 0.9$ & $3.6 \pm 0.9$ & $4.0 \pm 0.5$ \\
\hline Lower Buckland & $29.1-35.4$ & $4.7 \pm 0.8$ & $4.2 \pm 0.8$ & $5.4 \pm 0.9$ & $4.2 \pm 0.9$ & $4.6 \pm 0.6$ \\
\hline Myrtleford & $25.7-31.1$ & $5.8 \pm 0.8$ & $5.2 \pm 0.8$ & $6.7 \pm 1.0$ & $5.3 \pm 0.9$ & $5.8 \pm 0.7$ \\
\hline \multicolumn{7}{|c|}{ September 2014} \\
\hline Ovens East Branch & $52.7-64.1$ & $3.7 \pm 1.0$ & $3.5 \pm 0.8$ & $4.3 \pm 1.0$ & $3.4 \pm 0.8$ & $3.7 \pm 0.4$ \\
\hline Ovens West Branch & $43.4-52.6$ & $7.6 \pm 0.7$ & $7.0 \pm 0.7$ & $9.2 \pm 1.1$ & $7.2 \pm 0.6$ & $7.7 \pm 1.0$ \\
\hline Simmons CK & $6.7-8.1$ & $15.8 \pm 0.4$ & $13.6 \pm 0.0$ & $20.4 \pm 1.0$ & $13.1 \pm 0.1$ & $15.5 \pm 3.3$ \\
\hline Smoko & $23.2-28.1$ & $6.7 \pm 0.7$ & $6.1 \pm 0.8$ & $8.0 \pm 1.0$ & $6.3 \pm 0.7$ & $6.8 \pm 0.8$ \\
\hline Bright & & $6.2 \pm 0.8$ & $5.5 \pm 0.8$ & $7.2 \pm 1.0$ & $5.6 \pm 0.8$ & $6.1 \pm 0.8$ \\
\hline Upper Morses Ck & & $8.1 \pm 0.7$ & $7.5 \pm 0.6$ & $9.9 \pm 1.1$ & $7.8 \pm 0.5$ & $8.3 \pm 1.1$ \\
\hline Lower Morses Ck & $24.2-30.4$ & $10.3 \pm 0.6$ & $9.7 \pm 0.3$ & $13.2 \pm 1.1$ & $9.7 \pm 0.2$ & $10.7 \pm 1.7$ \\
\hline Upper Buckland & & $.0 \pm 0.7$ & $6.3 \pm 0.7$ & $8.3 \pm 1.0$ & $6.6 \pm 0.7$ & $7.0 \pm 0.9$ \\
\hline Lower Buckland & $29.1-35.4$ & $5.6 \pm 0.8$ & $5.0 \pm 0.8$ & $6.5 \pm 1.0$ & $5.0 \pm 0.9$ & $5.5 \pm 0.7$ \\
\hline Myrtleford & $25.7-31.1$ & $6.3 \pm 0.8$ & $5.6 \pm 0.8$ & $7.3 \pm 1.0$ & $5.7 \pm 0.8$ & $6.2 \pm 0.8$ \\
\hline
\end{tabular}

${ }^{a}$ Sites on Fig. 1. ${ }^{b}$ Runoff coefficient, range reflects likely rainfall range in catchments. ${ }^{c}$ Lumped parameter models: $\mathrm{EF}=$ exponential flow, $\mathrm{DM}=$ dispersion model, $\mathrm{EPF}=$ Exponential-Piston flow with EPM ratios of 0.33 and 1.0. ${ }^{\mathrm{d}}$ Model discussed in text. ${ }^{\mathrm{e}}$ Mean and standard deviation of mean transit time from the four models. ${ }^{\mathrm{f}}$ Uncertainty calculated from different values of modern rainfall input as discussed in text. 


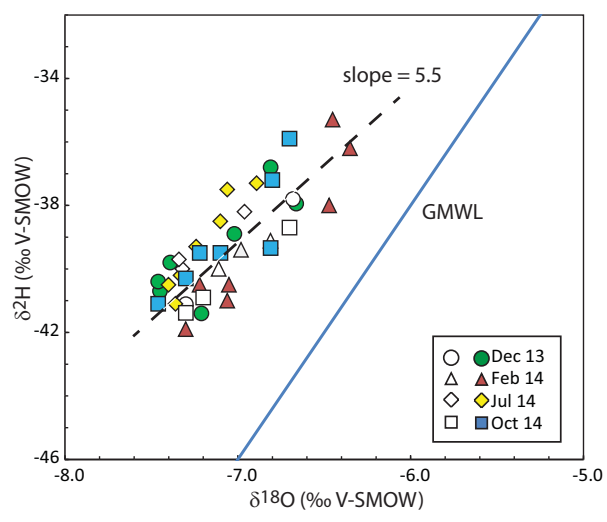

Figure 6. $\delta^{18} \mathrm{O}$ vs. $\delta^{2} \mathrm{H}$ values for the main Ovens River (open symbols) and its headwater tributaries (closed symbols) in the four sampling rounds; GMWL = Global Meteoric Water Line. Data from Table 1 .

to local climatic factors (Ivkovic et al., 1998; Leaney and Herczeg, 1999; Cartwright et al., 2012).

$\mathrm{Na}$ and $\mathrm{Cl}$ concentrations from the rainfall sample at Mount Buffalo are 0.97 and $1.1 \mathrm{mg} \mathrm{L}^{-1}$, respectively (Table 1), which are similar to the Na concentrations of 0.9 to $1.3 \mathrm{mg} \mathrm{L}^{-1}$ and $\mathrm{Cl}$ concentrations 1.2 to $1.4 \mathrm{~L}^{-1}$ reported for rainfall in this region of south-east Australia by Blackburn and McLeod (1983). Na and Cl concentrations in stream water from the Ovens catchment range from 2.4 to $5.5 \mathrm{mg} \mathrm{L}^{-1}$ and 0.82 to $3.5 \mathrm{mg} \mathrm{L}^{-1}$, respectively (Table 1 ). The concentrations of these and other major ions are higher during low-flow periods (February 2014) than during periods of higher flow. $\mathrm{Na} / \mathrm{Cl}$ mass ratios of the stream samples are between 1.4 and 4.2 which are higher than the $\mathrm{Na} / \mathrm{Cl}$ ratios of local rainfall of 0.7 to 0.9 (Table 1; Blackburn and McLeod, 1983). Since ${ }^{3} \mathrm{H}$ activities are inversely correlated with streamflow (Figs. 4 and 5), there is also a broad inverse correlation between ${ }^{3} \mathrm{H}$ activities and $\mathrm{Cl}$ and $\mathrm{Na}$ concentrations (Fig. 7).

A correlation between major ion concentrations and streamflow is also apparent on a longer timescale. Figure 8a shows the variation of streamflow and $\mathrm{Na}$ concentrations at Harrietville made as part of routine geochemical measurements (Department of Environment and Primary Industries, 2015). The Na concentrations range from 1.3 to $2.2 \mathrm{mg} \mathrm{L}^{-1}$ at high flows to $\sim 4.4 \mathrm{mg} \mathrm{L}^{-1}$ at low flows. As noted earlier, the Harrietville gauge records the combined streamflow from the Ovens East Branch and Ovens West Branch; however, the $\mathrm{Na}$ vs. streamflow trends for these two tributaries are similar to that from the Harrietville gauge (Fig. 8a), albeit with far less data.

\section{Discussion}

The combination of streamflow data, major ion concentrations, stable isotope geochemistry, and ${ }^{3} \mathrm{H}$ activities allow an
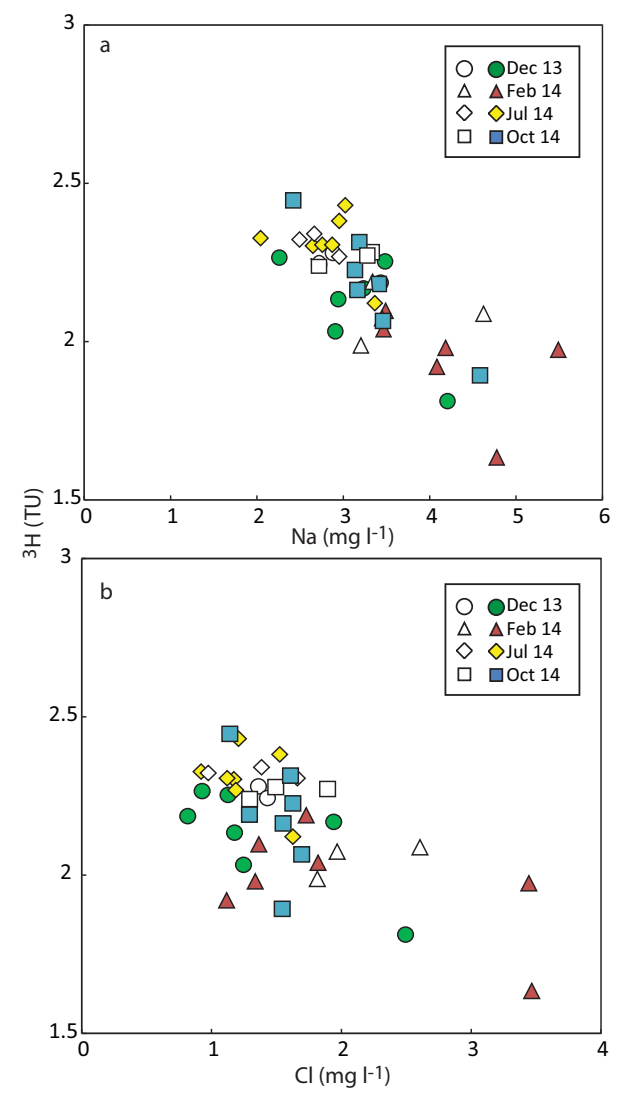

Figure 7. ${ }^{3} \mathrm{H}$ activities vs. $\mathrm{Na}$ (a) and $\mathrm{Cl}$ (b) concentrations for the main Ovens River (open symbols) and its headwater tributaries (closed symbols) in the four sampling rounds. Data from Table 1.

understanding of the hydrogeology of the upper Ovens catchment to be made.

\subsection{Changes to water stores with streamflow}

One fundamental question relating to catchment hydrology is the extent to which water in streams at high flows is event water largely derived from recent rainfall rather than older water displaced from stores within the catchment (Sklash and Farvolden, 1979; Rice and Hornberger, 1998; Uhlenbrook et al., 2002; Kirchner et al., 2010). Resolution of this question is important to interpreting ${ }^{3} \mathrm{H}$ activities. If significant dilution with event water occurs, any increases in ${ }^{3} \mathrm{H}$ activities in the stream with increasing flow (e.g. Figs. 4 and 5) may be the result of mixing between high ${ }^{3} \mathrm{H}$ event water and an older baseflow component, and the ${ }^{3} \mathrm{H}$ activities may be used to estimate the proportions of these two components (Morgenstern et al., 2010). By contrast, if water is displaced from the catchment during high rainfall events, the ${ }^{3} \mathrm{H}$ activities will reflect the mean transit time of that water and differences in ${ }^{3} \mathrm{H}$ activities with streamflow may reflect the mobilisation of water with different residence times from different parts of the catchment. 


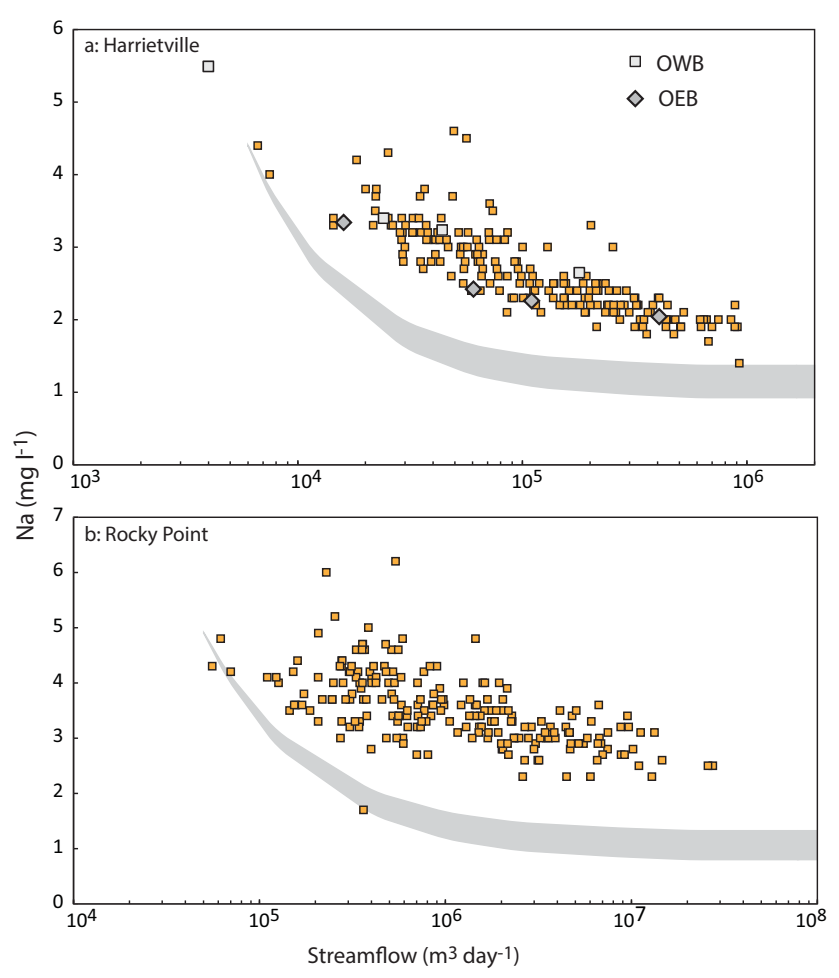

Figure 8. Na concentrations vs. streamflow for Harrietville (a) and Rocky Point (b), data from the Department of Environment and Primary Industries (2015). (a) also shows $\mathrm{Na}$ vs streamflow for the Ovens East Branch (OEB) and Ovens West Branch (OWB) tributaries which join just upstream of the Harrietville gauge (Fig. 1). Shaded fields depict mixing between baseflow, which is assumed to have a $\mathrm{Na}$ concentration of the lowest streamflow at each site, and rainfall with a $\mathrm{Na}$ concentration of 0.9 to $1.3 \mathrm{mg} \mathrm{L}^{-1}$ calculated using Eq. (4). The mixing model underestimates the Na concentration recorded at higher flows at both locations.

In the upper Ovens Valley only the Harrietville gauge, which records the combined East Branch and West Branch streamflow, has sufficient major ion data to assess the degree of mixing of baseflow with event water. Figure 8a shows the calculated Na vs. streamflow trends resulting from the mixing of event water and baseflow at the Harrietville gauge using Eq. (4) and the following assumptions: (1) Na concentrations at the lowest streamflow represents the $\mathrm{Na}$ concentrations of baseflow; (2) the baseflow remains constant at the value of the minimum streamflow, in this case $6600 \mathrm{~m}^{3} \mathrm{day}^{-1}$; and (3) rainfall has an Na concentration between 0.9 and $1.3 \mathrm{mg} \mathrm{L}^{-1}$ (Blackburn and McLeod, 1983). The calculated $\mathrm{Na}$ vs. mixing trend underestimates the observed $\mathrm{Na}$ concentrations in the stream at Harrietville. A similar conclusion is also made for $\mathrm{Na}$ concentrations at the Rocky Point gauge, which is $\sim 25 \mathrm{~km}$ downstream of Myrtleford (Fig. 8b).

Similar conclusions may be made from the ${ }^{3} \mathrm{H}$ activities, albeit the data sets are much smaller. Figure 4 shows pre- dicted ${ }^{3} \mathrm{H}$ activities vs. streamflow trends constructed using Eq. (4) with similar assumptions to those above, namely: (1) at low-flow conditions the streams derive all their water from baseflow that has ${ }^{3} \mathrm{H}$ activities of the February 2014 sampling campaign; (2) baseflow remains constant at the streamflow recorded in February 2014; and (3) rainfall has $\mathrm{a}^{3} \mathrm{H}$ activity between 2.5 and $3.0 \mathrm{TU}$ which spans the range of activities in Table 1. For all catchments the mixing trends overestimate the ${ }^{3} \mathrm{H}$ activities of the stream water.

That the $\mathrm{Na} / \mathrm{Cl}$ ratios of all stream samples, even those at high streamflow, exceed those of rainfall implies that some $\mathrm{Na}$ is derived from the dissolution of minerals, probably predominantly plagioclase feldspar, from the soils, regolith, or bedrock. As mineral dissolution occurs over timescales months to years (Edmunds et al., 1982; Bullen et al., 1996; Morgenstern et al., 2010; Cartwright and Morgenstern, 2012) this observation is also consistent with the interpretation that much of the water in the stream has been mobilised from within the catchment.

$\delta^{18} \mathrm{O}$ and $\delta^{2} \mathrm{H}$ values of stream water define arrays with slopes of 4-6 (Table 1, Fig. 6) that most likely reflects a combination of instream evaporation, especially in February 2014 , and possibly the altitude effect where stream water derived from rainfall at higher altitudes has lower $\delta^{18} \mathrm{O}$ and $\delta^{2} \mathrm{H}$ values (cf. Clark and Fritz, 1997). The observation that the $\delta^{18} \mathrm{O}$ and $\delta^{2} \mathrm{H}$ values are similar at different flows is consistent with the water contributing to the stream having been resident within the catchment for sufficient time that any seasonal variations in rainfall $\delta^{18} \mathrm{O}$ and $\delta^{2} \mathrm{H}$ values have homogenised by mixing.

Taken together the ${ }^{3} \mathrm{H}$ activities, major ion concentrations, and stable isotope values are most consistent with a significant component of water in the stream at all flow conditions being derived from stores within the catchment that have a transit time of several years. High rainfall results in increased recharge that displaces older water from the soils, regolith, and sediments into the stream. The variation in ${ }^{3} \mathrm{H}$ activities with streamflow (Fig. 4) probably reflects the variation in the transit times (discussed below) of water within these different stores and the variations in $\mathrm{Na}$ and $\mathrm{Cl}$ concentrations (Fig. 7) reflect differences in chemistry between the water stores in the catchment.

\subsection{Transit times of stream water in the Ovens catchment}

In common with studies of shallow groundwater flow elsewhere (Maloszewski et al., 1992; Cook and Bohlke, 2000; Morgenstern et al., 2010), the calculations of mean transit times (Table 2, Fig. 9) were made assuming that groundwater flow had both exponential and piston flow components where the distribution transit times are described by Eqs. (1) and (2). While the aquifers adjacent to the streams are unconfined and thus are likely to exhibit exponential flow, recharge through the unsaturated zone will most likely resemble pis- 


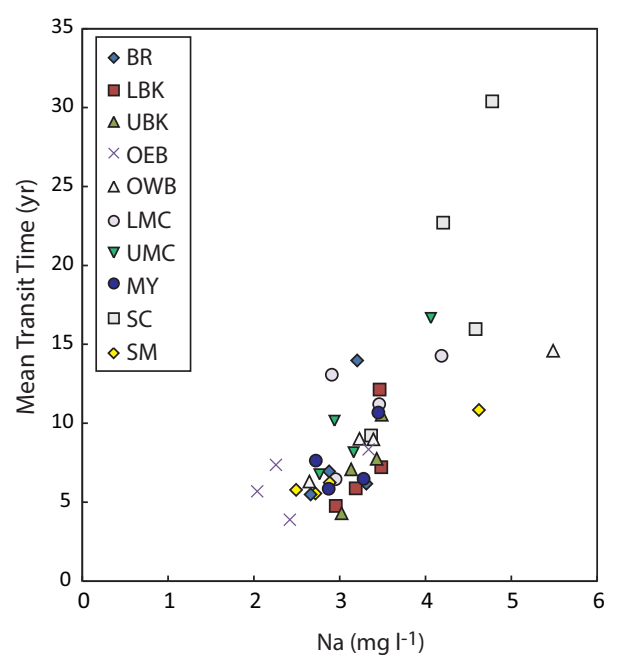

Figure 9. Mean transit times calculated using the ExponentialPiston Flow model vs. Na concentrations for the sites in the Ovens catchment (data from Tables 1 and 2). There is a broad correlation between mean transit time and $\mathrm{Na}$ concentration. $\mathrm{BR}=$ Bright, $\mathrm{LBK}=$ Lower Buckland, $\mathrm{LMC}=$ Lower Morses Creek, $\mathrm{MY}=$ Myrtleford, OEB = Ovens East Branch, OWB $=$ Ovens West Branch, $\mathrm{SC}=$ Simmons Creek, $\mathrm{SM}=$ Smoko, $\mathrm{UBK}=$ Upper Buckland, UMC $=$ Upper Morses Creek.

ton flow (Cook and Bohlke, 2000; Morgenstern et al., 2010). Initial calculations were carried out for $f=0.75$ (EPM ratio $=0.33$ ). Based on the variations of geochemistry with streamflow (Figs. 3 and 8) it was assumed that the water contributing to the streams during all sampling campaigns was from baseflow. If the stream contains some event water that is diluting the baseflow, this approach will yield a minimum transit time for the baseflow component.

The ${ }^{3} \mathrm{H}$ input function is based on the annual average ${ }^{3} \mathrm{H}$ activities of rainfall in Melbourne collected for the International Atomic Energy Agency Global Network of Isotopes in Precipitation program as summarised by Tadros et al. (2014). The ${ }^{3} \mathrm{H}$ activities of the two aggregated rainfall samples from the Ovens Valley of 2.85 and 2.99 TU (Table 1) are used to bracket the present-day rainfall ${ }^{3} \mathrm{H}$ activities. Rainfall ${ }^{3} \mathrm{H}$ activities reached $\sim 62 \mathrm{TU}$ in 1965 and then declined exponentially to present-day values by $\sim 1995$. ${ }^{3} \mathrm{H}$ activities of 2.85 and $2.99 \mathrm{TU}$ were also used for the pre-atmospheric nuclear test precipitation.

The exponential-piston flow model yields unique mean transit times for the range of measured ${ }^{3} \mathrm{H}$ activities in the Ovens catchment (Table 2, Fig. 9). The longest mean transit times at each site are from the low-flow period in February 2014 and range from 8 years at Ovens East Branch to 30 years at Simmons Creek. Stream water from the two Morses Creek sites has mean transit times of 14 to 17 years while mean transit times of stream water from the two Buckland River sites are 10 to 12 years. Mean transit times from the high-flow period (July 2014) calculating using the same exponential-flow model are between 4 years at Upper Buckland and 9 years at Simmons Creek (Table 2, Fig. 9). Mean transit times in the intermediate flow periods are between 7 and 23 years for December 2013 and 4 and 16 years for September 2014. In both these sampling campaigns Simmons Creek recorded the longest mean transit times while the shortest mean transit times were at Bright (December 2013) and Ovens East Branch (September 2014).

There are several uncertainties in these calculations that need to be assessed. Firstly, the calculated transit times vary with the choice of model (Table 2). Using the exponentialpiston flow model with $f=0.5($ EPM ratio $=1)$, which represents an aquifer system with equal portions of piston and exponential flow, yields mean transit times that range from 8 to 26 years in February 2014 and 4 to 9 years in July 2014. Using the exponential flow model $(f=1$, EPM ratio $=0)$, yields mean transit times that range from 10 to 35 years in February 2014 and 5 to 12 years in July 2014. The dispersion model with $D_{\mathrm{P}}=0.1$ yields mean transit times between 8 and 29 years in February 2014 and 4 to 9 years in July 2014. The absolute difference between the results from the models increases with the mean transit time. For the highest ${ }^{3} \mathrm{H}$ activity of 2.45 TU (Ovens East Branch in September 2014) the average mean transit time from the four models is $3.7 \pm 0.4$ years. For the lowest ${ }^{3} \mathrm{H}$ activity of $1.63 \mathrm{TU}$ (Simmons Creek in February 2014) the average mean transit time from the four models is $29.9 \pm 3.8$ years.

Allowing the ${ }^{3} \mathrm{H}$ activity of modern rainfall to vary between 2.85 and 2.99 also results in uncertainties in the calculated mean transit times. For the exponential-piston flow model with $f=0.75$, the standard deviation of the mean transit times decreases from $\sim 1.0$ years at 4 years to $<0.1$ years at $>20$ years, while the standard deviation of the mean transit times for the exponential-piston flow model with $f=0.5$ decreases from $\sim 0.9$ years at 4 years to $<0.1$ years at $>10$ years. The standard deviation of the mean transit times in the exponential flow model decreases from $\sim 0.9$ years at 4 years to $\sim 0.3$ years at 35 years but has a maximum value of $\sim 1.1$ years at 10 to 15 years, whereas the standard deviation of the mean transit times in the dispersion model decreases from $\sim 0.9$ years at 4 years to $<0.1$ years at 12 years. These differences reflect differences in the exit-age frequency distribution in the various models (e.g. Cook and Bohlke, 2000).

The analytical uncertainty of the ${ }^{3} \mathrm{H}$ activities produces uncertainties in the calculated mean transit times. The \pm 0.04 TU uncertainty for a sample with a ${ }^{3} \mathrm{H}$ activity of $2 \mathrm{TU}$ results in an uncertainty in mean transit time of approximately \pm 0.5 years. The assumptions that the ${ }^{3} \mathrm{H}$ activity of rainfall in the Ovens was identical to that in Melbourne and that the ${ }^{3} \mathrm{H}$ activity of the water that recharges the catchment is that of average rainfall are difficult to assess. However, these issues impact all of the catchments and result in uncertainties in the absolute not the relative mean transit times. Given the range of mean transit times, uncertainties in the 
rainfall ${ }^{3} \mathrm{H}$ activities before and during the bomb pulse have less impact than any uncertainties in the modern ${ }^{3} \mathrm{H}$ activities of rainfall.

Finally, the lumped parameter models are only an approximation of the flow through aquifer systems and real flow systems will differ to a greater or lesser extent. However, this will have little impact on the calculated variation in mean transit times in individual catchments at different streamflows as the flow systems within a specific catchment will likely be similar over time. Hence, while there are uncertainties in the calculated mean transit times, the conclusions that the mean transit times at the lowest flow conditions are on the order of years to decades while at higher flow conditions the mean transit times are at least a few years remain unaffected.

\subsection{Controls on transit times}

The mean transit times do not increase with catchment area and the smallest catchment (Simmons Creek) records the longest transit times (up to 30 years in February 2014). There is little difference in the geology or topography of the headwater sites implying that these are not factors which explain the variation in transit times between the catchments. Drainage density can influence transit times as it controls the distance between groundwater recharge areas and the nearest point of discharge in the stream (Morgenstern et al., 2015). In the case of the upper Ovens catchment, there is little difference in drainage density between the catchments, and many of the larger catchments have areas that are larger than the Simmons Creek catchment $\left(\sim 6 \mathrm{~km}^{2}\right)$ which are devoid of streams that flow during summer. These observations imply that drainage density is not the main control on transit times.

River water from the three floodplain sites along the main Ovens Valley (Smoko, Bright, and Myrtleford) have mean transit times that are not appreciably different from that of many of the headwater streams (Figs. 3 and 4), implying that there is not a large store of deep older groundwater contributing to baseflow in this stretch of the Ovens River. This conclusion is consistent with observations that the ${ }^{3} \mathrm{H}$ activities of shallow $(<40 \mathrm{~m})$ groundwater from the alluvial sediments in the Ovens Valley between Myrtleford and Bright are $>1 \mathrm{TU}$ with most having ${ }^{3} \mathrm{H}$ activities between 1.5 and 2.5 TU (Cartwright and Morgenstern, 2012).

There is a broad correlation between transit times and the runoff coefficient (Fig. 3). Evapotranspiration during recharge is a dominant hydrological process in south-east Australia and the native eucalyptus vegetation in particular has very high transpiration rates (Allison et al., 1990; Herczeg et al., 2001; Cartwright et al., 2012). While the catchments are similar, subtle differences in soil type which controls the rate of infiltration, vegetation density, or regolith thickness may influence evapotranspiration rates (Cartwright et al., 2006). Infiltration rates will vary inversely with the degree of evapotranspiration and catchments with high evapo- transpiration rates are likely to contribute smaller volumes of relatively old water to the streams draining those catchments.

Regardless of the cause, the correlation between the runoff coefficient and ${ }^{3} \mathrm{H}$ activities allows a first-order estimation of likely transit times in similar catchments to be made which is useful for management purposes. The correlation between $\mathrm{Na}$ and $\mathrm{Cl}$ concentrations and ${ }^{3} \mathrm{H}$ activities (Figs. 7 and 9) suggests that major ion geochemistry can also provide a firstorder indication of the mean transit times of baseflow. That the trends in $\mathrm{Na}$ ion concentrations and mean transit times from the different catchments overlap (Fig. 9) indicates that this approach may be useful in adjacent catchments with similar geology, topography, and vegetation.

\section{Conclusions and implications}

This study has demonstrated the utility of high-precision ${ }^{3} \mathrm{H}$ measurements in determining mean transit times of water in headwater catchments. The observation that the water contributing to the headwater streams in the Ovens catchment has mean transit times of years to decades implies that these streams are buffered against rainfall variations on timescales of a few years, and most of these streams continued to flow through the 1996-2010 Millennium drought (Bureau of Meteorology, 2015; Department of Environment and Primary Industries, 2015). However, the impacts of any changes to land use in these catchments or longer-term rainfall changes may take years to decades to manifest itself in changes to streamflow or water quality. If the conclusion that the mean transit times are controlled by the evapotranspiration rates in the catchments is correct, large-scale vegetation changes, for example replacing native forest by grassland that has lower transpiration rates, will cause a significant change in transit times. Specifically, lower transpiration rates will increase recharge that will likely result in development of shallow flow paths with short transit times and also increase the flow velocities in the deeper flow paths due to increased hydraulic heads. Both of these factors will likely reduce the mean transit times.

Author contributions. Both authors were involved in the design and realisation of the sampling program. U. Morgenstern carried out the ${ }^{3} \mathrm{H}$ analyses and I. Cartwright oversaw the analysis of the other geochemical parameters. I. Cartwright prepared the manuscript with contributions from U. Morgenstern.

Acknowledgements. Funding for this project was provided by Monash University and the National Centre for Groundwater Research and Training program P3. The National Centre for Groundwater Research and Training is an Australian Government initiative supported by the Australian Research Council and the National Water Commission via Special Research Initiative SR0800001. Massimo Raveggi and Rachael Pearson 
helped with the geochemical analyses at Monash University. Two anonymous reviewers and the editor (M. Hrachowitz) provided encouraging and helpful comments.

Edited by: M. Hrachowitz

\section{References}

Allison, G. B., Cook, P. G., Barnett, S. R., Walker, G. R., Jolly, I. D., and Hughes, M. W.: Land clearance and river salinisation in the western Murray Basin, Australia, J. Hydrol., 119, 1-20, 1990.

Blackburn, G. and McLeod, S.: Salinity of atmospheric precipitation in the Murray Darling Drainage Division, Australia, Austr. J. Soil Res., 21, 400-434, 1983

Bullen, T. D., Krabbenhoft, D. P., and Kendall, C.: Kinetic and mineralogic controls on the evolution of groundwater chemistry and ${ }^{87} \mathrm{Sr} /{ }^{86} \mathrm{Sr}$ in a sandy silicate aquifer, northern Wisconsin, USA, Geochim. Cosmochim. Acta, 60, 1807-1821, 1996.

Bureau of Meteorology: Commonwealth of Australia Bureau of Meteorology, available at: http://www.bom.gov.au, last access: March 2015.

Cartwright, I. and Morgenstern, U.: Constraining groundwater recharge and the rate of geochemical processes using tritium and major ion geochemistry: Ovens catchment, southeast Australia, J. Hydrol., 475, 137-149, 2012.

Cartwright, I., Weaver, T. R., Cendón, D. I., Fifield, L. K., Tweed, S. O., Petrides, B., and Swane, I.: Constraining groundwater flow, residence times, inter-aquifer mixing, and aquifer properties using environmental isotopes in the southeast Murray Basin, Australia, Appl. Geochem., 27, 1698-1709, 2012.

Cartwright, I., Weaver, T. R., and Fifield, L. K.: $\mathrm{Cl} / \mathrm{Br}$ ratios and environmental isotopes as indicators of recharge variability and groundwater flow: An example from the southeast Murray Basin, Australia, Chem. Geol., 231, 38-56, 2006.

Clark, I. D. and Fritz, P.: Environmental Isotopes in Hydrogeology, Lewis, New York, USA, 328 pp., 1997.

Cook, P. G.: Estimating groundwater discharge to rivers from river chemistry surveys, Hydrol. Process., 27, 3694-3707, 2013.

Cook, P. G. and Bohlke, J. K.: Determining timescales for groundwater flow and solute transport, in: Environmental Tracers in Subsurface Hydrology, edited by: Cook, P. G. and Herczeg, A. L., Kluwer, Boston, USA, 1-30, 2000.

Coplen, T. B.: Normalization of oxygen and hydrogen isotope data, Chem. Geol., 72, 293-297, 1988.

Department of Environment and Primary Industries: Victoria Department of Environment and Primary Industries Water Monitoring, available at: http://data.water.vic.gov.au/monitoring.htm, last access: March 2015.

Edmunds, W. M., Bath, A. H., and Miles, D. L.: Hydrochemical evolution of the East Midlands Triassic sandstone aquifer, England, Geochim. Cosmochim. Acta, 46, 2069-2081, 1982.

Energy and Earth Resources: State Government Victoria Energy and Earth Resources, available at: http: //www.energyandresources.vic.gov.au/earth-resources/ maps-reports-and-data/geovic, last access: March 2015.

Freeman, C. M., Pringle, C. M., and Jackson, C. R.: Hydrologic connectivity and the contribution of stream headwaters to eco- logical integrity at regional scales, J. Am. Water Resour. As., 43, 5-14, 2007.

Goulburn-Murray Water: Ovens Basin, available at: http://www. g-mwater.com.au/water-resources/catchments/ovensbasin, last access: April 2015.

Godsey, S. E., Kirchner, J. W., and Clow, D. W.: Concentrationdischarge relationships reflect chemostatic characteristics of US catchments, Hydrol. Process., 23, 1844-1864, 2009.

Herczeg, A. L., Dogramaci, S. S., and Leaney, F. W.: Origin of dissolved salts in a large, semi-arid groundwater system: Murray Basin, Australia, Mar. Freshwater Res., 52, 41-52, 2001.

Hrachowitz, M., Bohte, R., Mul, M. L., Bogaard, T. A., Savenije, H. H. G., and Uhlenbrook, S.: On the value of combined event runoff and tracer analysis to improve understanding of catchment functioning in a data-scarce semi-arid area. Hydrol. Earth Syst. Sci., 15, 2007-2024, doi:10.5194/hess-15-2007-2011, 2011.

Hrachowitz, M., Savenije, H., Bogaard, T. A., Tetzlaff, D., and Soulsby, C.: What can flux tracking teach us about water age distribution patterns and their temporal dynamics?, Hydrol. Earth Syst. Sci., 17, 533-564, doi:10.5194/hess-17-533-2013, 2013.

International Atomic Energy Association: Global Network of Isotopes in Precipitation, available at: http://www.iaea.org/water, last access: February 2015.

Ivkovic, K. M., Watkins, K. L., Cresswell, R. G., and Bauld, J.: A Groundwater Quality Assessment of the Upper Shepparton Formation Aquifers: Cobram Region, Victoria, Austr. Geol. Surv. Org. Record 1998/16, Austr. Geol. Surv. Org., Canberra, Australia, 1998.

Jurgens, B.C., Bohlke, J. K., and Eberts, S. M.: TracerLPM (Version 1): An Excel ${ }^{\circledR}$ workbook for interpreting groundwater age distributions from environmental tracer data, US Geol. Surv. Techniques and Methods Report 4-F3, US Geological Survey, Reston, USA, 60 pp., 2012.

Kirchner, J. W.: Catchments as simple dynamical systems: Catchment characterization, rainfall-runoff modeling, and doing hydrology backward, Water Resour. Res., 45, W02429, doi:10.1029/2008WR006912, 2009.

Kirchner, J. W.: Aggregation in environmental systems: catchment mean transit times and young water fractions under hydrologic nonstationarity, Hydrol. Earth Syst. Sci. Discuss., 12, 31053167, doi:10.5194/hessd-12-3105-2015, 2015.

Kirchner, J. W., Tetzlaff, D., and Soulsby, C.: Comparing chloride and water isotopes as hydrological tracers in two Scottish catchments, Hydrol. Process., 24, 1631-1645, 2010.

Lawrence, C. R.: Murray Basin, in: Geology of Victoria, edited by: Douglas J. G. and Ferguson, J. A., Geological Society of Australia (Victoria Division), Melbourne, Australia, 352-363, 1988.

Leaney, F. and Herczeg, A.: The origin of fresh groundwater in the SW Murray Basin and its potential for salinisation, CSIRO Land and Water Technical Report 7/99, CSIRO, Adelaide, Australia, 1999.

Maloszewski, P.: Lumped-parameter models as a tool for determining the hydrological parameters of some groundwater systems based on isotope data, IAHS-AISH Publication 262, Vienna, Austria, 271-276, 2000.

Maloszewski, P. and Zuber, A.: Determining the turnover time of groundwater systems with the aid of environmental tracers, 1. Models and their applicability, J. Hydrol., 57, 207-231, 1982. 
Maloszewski, P. and Zuber, A.: On the calibration and validation of mathematical models for the interpretation of tracer experiments in groundwater, Adv. Water Resour., 15, 47-62, 1992.

Maloszewski, P., Rauert, W., Trimborn, P., Herrmann, A., and Rau, R.: Isotope hydrological study of mean transit times in an alpine basin (Wimbachtal, Germany), J. Hydrol., 140, 343-360, 1992.

McCallum, J. L., Cook, P. G., Brunner, P., and Berhane, D.: Solute dynamics during bank storage flows and implications for chemical base flow separation, Water Resour. Res., 46, W07541, doi:10.1029/2009WR008539, 2010.

McDonnell, J. J., McGuire, K., Aggarwal, P., Beven, K. J., Biondi, D., Destouni, G., Dunn, S., James, A., Kirchner, J., Kraft, P., Lyon, S., Maloszewski, P., Newman, B., Pfister, L., Rinaldo, A., Rodhe, A., Sayama, T., Seibert, J., Solomon, K., Soulsby, C., Stewart, M., Tetzlaff, D., Tobin, C., Troch, P., Weiler, M., Western, A., Wörman, A., and Wrede, S.: How old is streamwater? Open questions in catchment transit time conceptualization, modelling and analysis, Hydrol. Process., 24, 1745-1754, 2010.

Morgenstern, U. and Daughney, C. J.: Groundwater age for identification of baseline groundwater quality and impacts of landuse intensification - The National Groundwater Monitoring Programme of New Zealand, J. Hydrol., 456-457, 79-93, 2012.

Morgenstern, U. and Taylor, C. B.: Ultra low-level tritium measurement using electrolytic enrichment and LSC, Isot. Environ. Healt. S., 45, 96-117, 2009.

Morgenstern, U., Stewart, M. K., and Stenger, R.: Dating of streamwater using tritium in a post nuclear bomb pulse world: Continuous variation of mean transit time with streamflow, Hydrol. Earth Syst. Sci., 14, 2289-2301, doi:10.5194/hess-14-22892010, 2010.

Morgenstern, U., Daughney, C. J., Leonard, G., Gordon, D., Donath, F. M., and Reeves, R.: Using groundwater age and hydrochemistry to understand sources and dynamics of nutrient contamination through the catchment into Lake Rotorua, New Zealand, Hydrol. Earth Syst. Sci., 19, 803-822, doi:10.5194/hess-19-803-2015, 2015.
Rice, K. C. and Hornberger, G. M.: Comparison of hydrochemical tracers to estimate source contributions to peak flow in a small, forested, headwater catchment, Water Resour. Res., 34, 17551766, 1998.

Shugg, A.: Hydrogeology of the Upper Ovens Valley, Victoria Department of Industry, Technology and Resources Report 1987/5, Melbourne, Australia, 1987.

Sklash, M. G. and Farvolden, R. N.: The role of groundwater in storm runoff, J. Hydrol., 43, 45-65, 1979.

Sophocleous, M.: Interactions between groundwater and surface water: the state of the science, Hydrogeol. J., 10, 52-67, 2002.

Stewart, M. K., Morgenstern, U., and McDonnell, J. J.: Truncation of stream residence time: How the use of stable isotopes has skewed our concept of streamwater age and origin, Hydrol. Process., 24, 1646-1659, 2010.

Tadros, C. V., Hughes, C. E., Crawford, J., Hollins, S. E., and Chisari, R.: Tritium in Australian precipitation: A 50 year record, J. Hydrol., 513, 262-273, 2014.

Tickell, S. J.: Geology and hydrogeology of the eastern part of the riverine plain in Victoria, Geological Survey of Victoria Report 1977-8, Melbourne, Australia, 73 pp., 1978,

Uhlenbrook, S., Frey, M., Leibundgut, C., and Maloszewski, P.: Hydrograph separations in a mesoscale mountainous basin at event and seasonal timescales, Water Resour. Res., 38, 3113114, 2002.

van den Berg, A. H. M. and Morand, V.: Wangaratta, Geological Survey of Victoria $1: 250,000$ Geological Map Series, Geological Survey of Victoria, Melbourne, Australia, 1997.

Winter, T. C.: Relation of streams, lakes, and wetlands to groundwater flow systems, Hydrogeol. J., 7, 28-45, 1999.

Zuber, A., Witczak, S., Rozanski, K., Sliwka, I., Opoka, M., Mochalski, P., Kuc, T., Karlikowska, J., Kania, J., JackowiczKorczynski, M., and Dulinski, M.: Groundwater dating with ${ }^{3} \mathrm{H}$ and $\mathrm{SF}_{6}$ in relation to mixing patterns, transport modelling and hydrochemistry, Hydrol. Process., 19, 2247-2275, 2005. 